Al Qalam: Jurnal Ilmiah Keagamaan dan Kemasyarakatan

Vol. 13, No. 1, 2019

P-ISSN: 1907-4174; E-ISSN: 2621-0681

\title{
PENDIDIKAN ISLAM DI KABUPATEN TABALONG: SEKOLAH ISLAM SEBAGAI GERAKAN SOSIAL
}

Oleh:

Rabi’ah

Dosen, Sekolah Tinggi Agama Islam Rakha Amuntai

Kalimantan Selatan

\begin{abstract}
Abstrak
Kabupaten Tabalong merupakan daerah berkembang di Provinsi Kalimantan Selatan yang perkembangannya dinilai sangat pesat dibandingkan dengan kabupaten lain. Jumlah penduduk terbanyak kedua (ke-2) setelah HST. Hal ini menjadikan Kabupaten Tabalong sebagai ruang potensial untuk berbagai bidang, di antaranya perdagangan, industri, bahkan pendidikan. Lebih khusus pendidikan Islam karena Islam merupakan agama mayoritas penduduk Kabupaten Tabalong. Pertumbuhan lembaga pendidikan Islam di Kabupaten Tabalong cukup pesat. Beriringan dengan pelaksanaan otonomi daerah di bidang pendidikan yang memberikan peluang kepada berbagai gerakan sosial keagamaan untuk memprentasikan keberadaannya. Gerakan sosial keagamaan menentukan corak ideologis pendidikan Islam di suatu wilayah. Artikel ini bertujuan untuk mendeskripsikan sekolah Islam sebagai salah satu bentuk lembaga pendidikan Islam di Kabupaten Tabalong meliputi keberadaannya, segmentasi konsumennya, dan organisasi/yayasan pendirinya. Teori yang digunakan sebagai pisau analisis dalam artikel ini adalah teori gerakan sosial (Social Movement). Keberadaan sekolah Islam tidak terlepas dari gerakan-gerakan sosial keagamaan di Kabupaten Tabalong yang mendapatkan peluang dari pelaksanaan otonomi daerah dan pemerintah daerah yang moderat serta perekonomian daerah yang berkembang.
\end{abstract}

Kata Kunci: Pendidikan Islam, Sekolah Islam, Gerakan Sosial 
Rabi'ah: Pendidikan Islam di Kabupaten Tabalong: Sekolah Islam Sebagai Gerakan Sosial

\section{A. Pendahuluan}

Perekonomian merupakan tulang punggung dari kehidupan bangsa yang dapat menentukan maju mundurnya, lemah kuatnya, lambat cepatnya suatu proses perkembangan sistem pendidikan dalam masyarakat bangsa. Oleh karena itu, kehidupan ekonomi di suatu wilayah mempengaruhi pertumbuhan lembaga pendidikan. Bahkan juga mempengaruhi sistem pendidikan yang diberlakukan serta kelembagaan kependidikan yang dapat mengembangkan sistem ekonomi yang diinginkan. ${ }^{1}$

Kabupaten Tabalong merupakan daerah berkembang di Provinsi Kalimantan Selatan yang perkembangannya dinilai sangat pesat dibandingkan dengan kabupaten lain. Jumlah penduduk terbanyak kedua (ke-2) setelah HST. Hal ini menjadikan Kabupaten Tabalong sebagai pasar potensial berbagai bidang, di antaranya perdagangan, industri, bahkan pendidikan. Mayoritas penduduk Tabalong beragama Islam. Sehingga, Pendidikan Islam memiliki peluang yang besar untuk menjadi pilihan utama masyarakat Tabalong.

Muhaimin mendefinisikan pendidikan Islam ke dalam 2 (dua pengertian), sebagai berikut: ${ }^{2}$

Definisi pertama, pendidikan Islam merupakan aktivitas pendidikan yang diselenggarakan atau didirikan dengan hasrat dan niat untuk mengejawantahkan ajaran dan nilai-nilai Islam, yaitu:

1) Pondok pesantren atau Madrasah Diniyah, yang menurut UU No. 20 tahun 2003 tentang Sistem Pendidikan Nasional disebut sebagai pendidikan keagamaan (Islam) formal, seperti Pondok Pesantren/Madrasah Diniyah (Ula, Wustha, 'Ulya, dan Ma'had 'Ali;

\footnotetext{
${ }^{1}$ Akmal Hawi, "Tantangan Lembaga Pendidikan Islam," Tadrib: Jurnal Pendidikan Agama Islam 3 (August 30, 2017): 143, https://doi.org/10.19109/Tadrib.v3i1.1388.h. 150.

${ }^{2}$ Muhaimin M.A, Manajemen Pendidikan (Aplikasinya dalam Penyusunan Rencana Pengembangan Sekolah / Madrasah) (Prenada Media, 2015)., h. 3.
} 
Rabi'ah: Pendidikan Islam di Kabupaten Tabalong: Sekolah Islam Sebagai Gerakan Sosial

2) PAUD/RA, BA, TA, Madrasah, dan pendidikan lanjutannya seperti IAIN/STAIN atau Universitas Islam Negeri yang benaung di bawah Departemen Agama;

3) Pendidikan usia dini/RA, BA, TA, sekolah/perguruan tinggi yang diselenggarakan oleh dan/atau berada di bawah naungan yayasan dan organisasi Islam;

4) Pelajaran Agama Islam di sekolah/madrasah/perguruan tinggi sebagai suatu mata pelajaran atau mata kuliah, dan/atau sebagai program studi; dan

Definisi kedua pendidikan Islam merupakan pelajaran Islam dalam keluarga atau di tempat-tempat ibadah, dan/atau di forum-forum kajian keislaman, majelis taklim, dan institusi-institusi lainnya yang sekarang sedang digalakkan oleh masyarakat, atau pendidikan (Islam) melalui jalur pendidikan nonformal, dan informal. Berdasarkan 2 (dua) definisi di atas, pembahasan dalam artikel ini adalah mengenai pendidikan Islam yang diselenggarakan oleh dan/atau berada di bawah naungan yayasan dan organisasi Islam.

Karen Bryner dalam disertasinya telah melakukan penelitian untuk memahami persimpangan gerakan Islam, pendidikan Islam, dan kelas menengah agama. ${ }^{3}$ Bryner juga menjelaskan bahwa ada beberapa trend sekolah Islam, yakni JSIT (Jaringan Sekolah Islam Terpadu), Jaringan Sekolah Integral Hidayatullah, dan Sekolah Islam Al Azhar (Muhammadiyah). ${ }^{4}$

\section{B. Sejarah Sekolah Islam di Indonesia}

Pada awal abad XX (kedua puluh), pesantren mendominasi pengaruh dalam pendidikan Islam, kaum modernis menyayingi itu dengan memperkenalkan jenis baru sekolah agama, yang mereka sebut dengan “madrasah". Madrasah pertama didirikan pada tahun 1910-an dan 1920-an oleh

\footnotetext{
${ }^{3}$ Karen Bryner, "Piety Projects: Islamic Schools for Indonesia's Urban Middle Class" (Disertasi tidak diterbitkan, Teacher College, School of Art and Sciences, Columbia University, New York, 2013).

${ }^{4}$ Karen Bryner, "Piety Projects: Islamic Schools for Indonesia's Urban Middle Class," 2013. H. 55-56
} 
Rabi'ah: Pendidikan Islam di Kabupaten Tabalong: Sekolah Islam Sebagai Gerakan Sosial

kelompok reformasi pendidikan Islam seperti di Singapura, Sumatra Barat, dan Jawa Tengah-Selatan. Pada awal perang dunia Kedua, madrasah telah menyebar ke Thailand Selatan, Kalimantan, Sulawesi, dan bahkan sampai ke Kamboja. ${ }^{5}$

Meskipun, tidak seperti di bagian lain di Asia Tenggara, kelompok tradisionalis Islam di Indonesia terus menikmati dukungan populer yang lebih luas daripada kelompok modernis, kelompok modernis seperti Muhammadiyah (didirikan tahun 1912) menggunakan gaya manajemen yang terinspirasi Barat. Muhammadiyah membangun jaringan kelembagaan yang sampai saat ini terdiri dari ribuan sekolah, puluhan rumah sakit, dan sekitar 166 fakultas pendidikan tinggi, yang sebagian besar menawarkan profesional umum serta pendidikan Islam. ${ }^{6}$

Karel A Steenbrink menjelaskan bahwa ada empat faktor pendorong bagi perubahan Islam pada awal abad XX di Indonesia, yakni: pertama munculnya keinginan kembali kepada Al Qur'an dan Hadits yang dijadikan sebagai titik tolak untuk menilai kebiasaan agama dan kebudayaan yang ada; Kedua, Perlawanan nasional terhadap penguasa kolonial Belanda; Ketiga, usaha kuat dari orang-orang Islam untuk memperkuat organisasinya dalam bidang sosial ekonomi; Keempat, adanya pembaharuan dalam bidang pendidikan Islam. ${ }^{7}$

Fenomena pembaharuan pendidikan ini tidak bisa dilepaskan dari kemunculan gerakan pembaharuan di Indonesia. Gerakan pembaharuan tersebut dilakukan baik secara individu maupun kelompok. Secara individu muncul tokoh-tokoh seperti Syaikh Thaher Jalaluddin, Syaikh Muhammad Djamil Djambek, Haji Rasul, Haji Abdullah Ahmad, Syaikh Ibrahim Musa, dan

\footnotetext{
${ }^{5}$ Robert W. Hefner, Making Modern Muslims: The Politics of Islamic Education in Southeast Asia, 2008, http://gen.lib.rus.ec/book/index.php?md5=B5FE48F2C034307C3D61ABB3E7DAAA9 F. H. 22.

${ }^{6}$ Hefner.h. 26 dan Muhammad Fuad

${ }^{7}$ Karel A Steenbrink, Pesantren, Madrasah, Sekolah: Pendidikan Islam Dalam Kurun Moderen (Lembaga Penelitian, Pendidikan dan Penerangan Ekonomi dan Sosial, 1986).h. 26-28.
}

Al Qalam: Jurnal Ilmiah Keagamaan dan Kemasyarakatan Vol. 13, No. 1, Januari-Juni 2019 
Rabi'ah: Pendidikan Islam di Kabupaten Tabalong: Sekolah Islam Sebagai Gerakan Sosial

Zainuddin Labai El Yunusi. Secar kelompok, muncul sejumlah organisasi Islam seperti Nahdatul Ulama (NU), Muhammadiyah, Persyarikatan Ulama, Persatuan Islam, Sarekat Islam, Jami'at al Khair, al Irsyad, dan Jami'atul Washliyyah.

Manfred Ziamek menjelaskan bahwa pendidikan Islam di Indonesia harus bertarung dengan pengaruh pendidikan Barat secara intensif: a) dalam paruh pertama abad 20 dengan bentuk pengajaran umum dari pemerintah kolonial. b) sejak kemerdekaan Indonesia dengan tradisi "pendidikan barat modern" yang dijadikan sistem pendidikan resmi di Indonesia. ${ }^{8}$

Pasca-Orde Baru, gerakan keagamaan memperoleh ruang yang cukup besar dalam mempresentasikan dirinya. Memasuki era reformasi, pertarungan antara pendidikan Islam, demokrasi dan perubahan sosial ditandai oleh munculnya gerakan-gerakan sosial keagamaan. ${ }^{9}$ Gerakan-gerakan sosial keagamaan ini tidak hanya lahir dari respons lokalitas keIndonesiaan sebagaimana Muhammadiyah dan NU, tetapi juga hubungan yang bersifat transnasional seperti Jamaah Islamiyah, Gerakan Tarbiyah, Majelis Mujahidin, Hizbut Tahrir dan kelompok Salafi Wahabi. ${ }^{10}$

Jamhari Makruf menjelaskan bahwa indikator perkembangan pendidikan Islam pascaordebaru ada tiga (3) yaitu: ${ }^{11}$ Pertama, jumlah madrasah dan pesantren dengan manajemen modern tumbuh pesat di kota-kota besar; Kedua, kebanyakan madrasah dan pesantren mencoba mengkombinasikan porsi yang seimbang baik dalam pengetahuan sekuler maupun Islam; Ketiga, muncul sekolah Islam, sebuah genre baru dalam pendidikan Islam di Indonesia. Berbeda dari pesantren dan madrasah yang berada di bawah pengawasan Departemen Agama (sekarang Kemenag), sekolah Islam yang menekankan ajaran Islam

\footnotetext{
${ }^{8}$ Manfred Ziamek, Pesantren Islamische Bildung In Sozialen Wandel,terj. (P3M), h. 1.

${ }^{9}$ Robert WHefner, Making Modern Muslims.

${ }^{10}$ Martin Van Bruinessen, Contemporary Developments in Indonesian Islam: Explaining the Conservative Turn, New ed. (Institute of Southeast Asian Studies, 2013), http://gen.lib.rus.ec/book/index.php?md5=18628023122209cb46aef3327730148c.

11 . Jamhari, "New Trend of Islamic Education in Indonesia," Studia Islamika 16, no. 2 (August 31, 2009), https://doi.org/10.15408/sdi.v16i2.482. H. 243-244.
} 
Rabi'ah: Pendidikan Islam di Kabupaten Tabalong: Sekolah Islam Sebagai Gerakan Sosial

praktis berada di bawah administrasi Departemen Pendidikan Nasional (sekarang kemendiknas).

Jamhari juga mengambarkan peta pendidikan Islam di Indonesia kontemporer yang mulai berubah. Ditandai antara lain dengan munculnya institusi pendidikan Islam yang tidak berafiliasi dengan organisasi massa yang mapan seperti Muhammadiyah dan NU. Karakteristik utama institusi tersebut adalah kecenderungannya untuk mengembangkan ideologi keagamaan salafi. ${ }^{12}$ Misalnya Hidayatullah berdiri pada tahun 1976, disebut sebagai perwujudan dari pemahaman Islam salafiyah. Pandangan ini dipresentasikan dalam ajaran-ajaran yang dikembangkan oleh ustadz Abdullah Said yang menginginkan berdirinya Jamaah Islamiyah yang mengimplementasikan penuh ajaran Islam dalam kehidupan masyarakat.

Sekolah Islam juga menjadi nomenklatur baru sistem pendidikan Islam di Indonesia pada abad XX. Sekolah Islam tumbuh bersamaan dengan terjadinya santrinisasi Transformasi ini bertepatan dengan kebangkitan kesadaran religius baru di kalangan Muslim Indonesia pada 1990-an, yang dikenal sebagai periode santrinisasi (santrinization yang berarti menjadi lebih saleh) atau Islamisasi (Islamisasi). Yon Machmudi memperkenalkan 3 (tiga) tipe "new"santri, yakni convergent, radical, dan global. ${ }^{13}$ Santri yang digambarkan sebagai konvergen adalah aktivis tradisionalis dan modernis yang cenderung bergabung satu sama lain. Santri radikal biasanya pesimis tentang perjuangan tradisionalis dan modernis dalam Islam dan menuntut perubahan radikal di Indonesia. Santri global lebih dipengaruhi oleh gerakan transnasional di timur tengah, namun masih merupakan bagian dari kelompok tradisionalis dan modernis di negara asal mereka.

Santrinisasi terjadi di kalangan generasi baru dan muda yang kebanyakan Muslim kelas menengah di daerah perkotaan seperti Jakarta,

\footnotetext{
${ }^{12}$ Jamhari. H. 244

${ }^{13}$ Yon Machmudi, "The Emergence of New Santri in Indonesia," Journal of Indonesian Islam 2, no. 1 (2008): 69.
} 
Rabi'ah: Pendidikan Islam di Kabupaten Tabalong: Sekolah Islam Sebagai Gerakan Sosial

Bandung, Yogyakarta, Surabaya, Medan, dan Makasar. Banyak yang lulus dari universitas terkemuka baik di Indonesia maupun di luar negeri. Mereka memiliki pengetahuan tentang kemajuan dalam sains dan teknologi, tetapi tidak memiliki pendidikan agama. Namun, mereka ingin anak-anak mereka untuk lebih memahami dan mempraktikkan ajaran Islam. Mereka menginginkan lembaga pendidikan Islam yang dapat memenuhi kebutuhan mereka. ${ }^{14}$.

Gagasan Sekolah Islam tidak dapat dipisahkan dari gagasan Muhammadiyah, yang memiliki tujuan untuk mengembangkan "HIS met de Qur'an" . Pembentukan Asosiasi Intelektual Muslim Indonesia (ICMI), yang memperoleh dukungan politik dari pemerintah, telah menjadi pilar kedua pertumbuhan Sekolah Islam di Indonesia.

Sekolah Islam digunakan untuk merujuk ke lembaga pendidikan yang menekankan transmisi pengetahuan Islam dan penanaman nilai-nilai dan etos Islam. Banyak sekolah Islam ditemukan di daerah perkotaan dan melayani sebagian besar siswa Muslim dari latar belakang keluarga kelas menengah. Sehingga menimbulkan persepsi umum bahwa mereka adalah sekolah Islam elit. Keinginan orang tua kelas menengah yang ingin memberikan sekolah Islam modern untuk anak-anak mereka yang menawarkan standar akademik yang tinggi dalam mata pelajaran umum dalam lingkungan Islam. ${ }^{15}$ Sekolah Islam umumnya memiliki fasilitas dan peralatan yang lebih baik, lebih banyak guru yang berkualitas, dan sumber daya lain yang diperlukan untuk kurikulum terpadu dan inovasi pendidikan.

Sekolah Islam Al Azhar adalah sekolah Islam tertua (berdiri tahun 1960) dan salah satu yang paling terkemuka. Didirikan oleh Haji Abdul Malik Karim Amrullah, salah seorang tokoh Muhammadiyah. Sekolah Islam Al Azhar

\footnotetext{
${ }^{14}$ Azyumardi Azra, "Reforms in Islamic Education: A Global Perspective Seen from the Indonesian Case," Dalam Paul Anderson, et. All (Ed), Reforms in Islamic Education,(University of Cambridge, 2011), 2014. H. 68. Lihat juga Jamhari ., "New Trend of Islamic Education in Indonesia." h. 244, 259.

${ }^{15}$ Charlene Tan, Islamic Education and Indoctrination: The Case in Indonesia (Routledge, 2012). h. 94.
} 
Rabi'ah: Pendidikan Islam di Kabupaten Tabalong: Sekolah Islam Sebagai Gerakan Sosial

berkembang pesat dan berhasil memiliki sejumlah cabang di berbagai kota besar di Indonesia. ${ }^{16}$ Sejak 1990an berdiri sekolah Madania, yang memiliki hubungan dengan Paramadina, sebuah lembaga yang didirikan Nurcholis Madjid. Sekolah Madania adalah lembaga pendidikan Islam pertama yang mempelopori pengembangan gagasan pluralism dan multikulturalisme di sekolah. ${ }^{17}$

\section{Teori Gerakan Sosial}

Teori gerakan sosial adalah salah satu dari berbagai teori tentang perubahan sosial. Konsep gerakan sosial secara teoritis merupakan sebuah gerakan yang terbangun berdasarkan prakarsa masyarakat dengan tujuan untuk melontarkan tuntutan atas perubahan dalam institusi maupun kebijakan dari pemerintah yang dirasa sudah maupun tidak sesuai lagi dengan kehendak sebagian masyarakat.

Menurut Anthony Giddens gerakan sosial didefinisikan sebagai upaya kolektif untuk mencapai kepentingan maupun tujuan bersama melalui tindakan kolektif terlepas dari intervensi dari lembaga-lembaga mapan. ${ }^{18}$ Gerakan sosial dilahirkan dengan kondisi yang memberikan kesempatan bagi gerakan itu. Seperti halnya pemerintahan yang moderat cenderung lebih memberikan kesempatan besar bagi kelahiran gerakan sosial ketimbang pemerintahan yang sangat otoriter.

Sekolah Islam-sekolah Islam di Indonesia setidaknya memiliki kemiripan sebagian dengan gerakan sosial yang menjadi perhatian para ahli teori politik dalam beberapa tahun terakhir. Dalam frasa yang sering dikutip Sidney Tarrow, gerakan sosial adalah "tantangan kolektif, berdasarkan tujuan bersama dan solidaritas sosial, dalam interaksi berkelanjutan dengan para elit,

${ }^{16}$ Jamhari., "New Trend of Islamic Education in Indonesia." h. 244

${ }^{17}$ Jamhari . h. 244.

${ }^{18}$ Anthony Gidden and Philip W Sutton (2010) Sociology: Introductory Reading (3 rd Edition), Polity Press, UK, 1993, h. 642 dalam Mohammad Syawaludin, Sosiologi Perlawanan Studi Perlawanan Repertoar Petani Idi Rengas Ogan Ilir Sumatera Selatan (Deepublish, 2017). h. 33. 
Rabi'ah: Pendidikan Islam di Kabupaten Tabalong: Sekolah Islam Sebagai Gerakan Sosial

lawan, dan pihak berwenang"19 dan mencari perubahan mendasar pada lembaga dan hierarki yang ada. ${ }^{20}$ Sidney Tarrow menjelaskan, bahwa sifat dasar dari gerakan sosial ada 3, yaitu pertama tantangan kolektif (collective challenge), kedua, tujuan bersama (common purpose), dan ketiga membangun solidaritas (social solidarity) melalui struktur ikatan dan identitas kolektif untuk mempertahankan aksi kolektif (sustained interaction). ${ }^{21}$ Ilim Abdul Halim menjelaskan ciri-ciri tersebut sebagai berikut: ${ }^{22}$

1. Tantangan kolektif (collective challenge)

Adanya tantangan yang mengharuskan dipilihnya perlawanan melalui aksi langsung terhadap pemegang otoritas, kelompok atau aturan kultural lainnya. Agenda tersebut merupakan cara untuk menarik perhatian konstituen, pihak ketiga atau pihak lawan.

2. Tujuan bersama (common purpose)

Adanya klaim bersama untuk menentang pihak lawan, pemegang otoritas atau elite, merupakan tujuan berpartisipasinya masyarakat dalam gerakan.

3. Solidaritas sosial (social solidarity)

Gerakan sosial akan terjadi jika pemimpin atau aktor menggali lebih dalam solidaritas sosial. Solidaritas yang dimiliki suatu kelompok dapat membentuk identitas yang biasanya bersumber dari nasionalisme, etnisitas, dan keyakinan agama.

${ }^{19}$ Sidney G. Tarrow, Power in Movement Social Movements and Contentious Politics Revised and Updated Third Edition, Cambridge Studies in Comparative Politics (Cambridge University Press, 2011) http://gen.lib.rus.ec/book/index.php?md5=077904571daf7855baf991e97ad973e0.

${ }^{20}$ Quintan wiktorowicz, Islamic Activism: Social Movement Approach, (Bloomingtoon: Indiana University Press, 2004) dalam Hefner, Making Modern Muslims. .

${ }^{21}$ Tarrow, Power In Movement Social Movements And Contentious Politics Revised And Updated Third Edition. h. 8

${ }^{22}$ Ilim Abdul Halim, "Gerakan Sosial Keagamaan Nahdlatul Ulama Pada Masa Kebangkitan Nasional," Religious: Jurnal Studi Agama-Agama Dan Lintas Budaya 2, no. 1 (2017): 35-50, https://doi.org/10.15575/rjsalb.v2i1.2215.

Al Qalam: Jurnal Ilmiah Keagamaan dan Kemasyarakatan Vol. 13, No. 1, Januari-Juni 2019 
Rabi'ah: Pendidikan Islam di Kabupaten Tabalong: Sekolah Islam Sebagai Gerakan Sosial

4. Memelihara interaksi (sustained interaction)

Ciri ini menunjukkan pemeliharaan aksi kolektif dalam interaksi dengan pihak lawan. Pemeliharaan interaksi ini merupakan faktor penting yang menandai sebuah penentangan dan berubah menjadi gerakan sosial.

\section{Deskripsi Sekolah Islam di Kabupaten Tabalong}

Pesantren dan madrasah tidak lagi memonopoli pendidikan Islam di Kabupaten Tabalong. Pun juga lembaga pendidikan Islam berbasis dakwah tidak lagi dimonopoli oleh NU dan Muhammadiyah. Sejak didirikan ponpes Hidayatullah oleh perkumpulan Hidayatullah tahun 2006 di desa Maburai kec. Murung Pudak, dan diresmikannya SD Hasbunallah tahun 2007 di kel. Mabuun kec. Murung Pudak. SD Hasbunallah merupakan sekolah Islam pertama yang bukan berbasis organisasi dakwah, merupakan hasil kerjasama masyarakat dengan mitra perusahaan (waktu itu dengan PT. Pama Persada) bersistem fullday school di Kabupaten Tabalong. Kurikulumnya perpaduan antara kurikulum kemendikbud dengan kurikulum pendidikan Islam Hasbunallah. Sekolah Islam Hasbunallah mengembangkan dirinya dengan membuka pesantren terpadu berbasis tahfiz al Qur'an. ${ }^{23}$

Sekolah Islam Muhammadiyah berada dalam lokasi yang tidak jauh dari Sekolah Islam Hasbunallah, masih terdapat dalam suatu wilayah Kelurahan Mabuun. Sekolah Islam Muhammadiyah mengembangkan dirinya dengan membuka Sekolah Alam Muhammadiyah jenjang SMP.

Yayasan Ashabul Kahfi, Jaringan Sekolah Islam Terpadu di kabupaten Tabalong memulai debut dengan didirikannya TKIT Rumah Lebah pada tahun 2009 di kel. Mabuun kec. Murung Pudak, karena besarnya permintaan masyarakat untuk sekolah lanjutan setelah tamat dari TKIT didirikanlah SDIT an-Nahl pada tahun 2011 yang sekarang sudah memiliki bangunan tetap di

\footnotetext{
${ }^{23}$ Sekolah Islam Hasbunallah mendirikan ponpes Nurul Mustofa pada tahun 2012 yakni ponpes terpadu berbasis tahfiz Al Qur'an yang sekaligus juga mengikuti kurikulum madrasah dari kemenag sehingga lulusannya mendapat ijazah yang diakui oleh pemerintah.
}

Al Qalam: Jurnal Ilmiah Keagamaan dan Kemasyarakatan

Vol. 13, No. 1, Januari-Juni 2019 
Rabi'ah: Pendidikan Islam di Kabupaten Tabalong: Sekolah Islam Sebagai Gerakan Sosial

Tanjung Selatan, kec. Murung Pudak. SMPIT di kel. Mabuun Kec. Murung Pudak. Yang menarik adalah pada September 2018 didirikan SDIT al Risalah bertempat di kel. Belimbing Kec. Murung Pudak, dan pendirinya adalah ustadz Rahman A, S. Pd. dan istrinya, ustadzah Salasiah, S. P. Beliau berdua adalah pendiri SDIT an-Nahl. ustadzah Salasiah, S. P. menjabat kepala sekolah SDIT an-Nahl pada tahun 2011-2015, dilanjutkan oleh ustadz Rahman A, S. Pd. pada tahun 2015-2017. Karena banyaknya masyarakat peminat dan terbatasnya rombongan belajar, maka SDIT an-Nahl tidak bisa menampung siswa lagi. Ustadz Rahman A, S. Pd. berinisiatif mendirikan yayasan baru, yakni yayasan al-Risalah dan SDIT al-Risalah di kel. Belimbing, masih dalam satu kecamatan, yakni kec. Murung Pudak. Cita-cita beliau adalah pemerataan SIT di tiap kecamatan yang termasuk wilayah perkotaan, dan segmentasi yang dipilih adalah kelas menengah. ${ }^{24}$

Hampir semua sekolah Islam di Kabupaten Tabalong berada di wilayah suburban yakni wilayah perkotaan Tanjung. Adapun yang berada di bagian pedesaan adalah sekolah Islam di bawah yayasan ponpes Al Madaniyah Jaro di Desa Nalui Kecamatan Jaro.

Lembaga pendidikan berbasis dakwah yang sepi peminat di kabupaten Tabalong, yakni Sekolah Islam Integral Hidayatullah, desa Maburai kec. Murung Pudak milik perkumpulan Hidayatullah. ${ }^{25}$ Pondok ini berdiri tahun 2006, memiliki beberapa unit pendidikan termasuk SD Integral Hidayatullah. Ponpes Hidayatullah desa Maburai ini merupakan cabang dari ponpes Hidayatullah Balikpapan yang didirikan oleh Ustadz Abdullah Said.

\section{E. Analisis}

Otonomi daerah yang diundang-undangkan pada tahun 1999, disambut baik secara nasional juga sampai ke daerah-daerah. Khususnya otonomi daerah

\footnotetext{
${ }^{24}$ Wawancara dengan ustadz Rahman A, S. Pd tanggal 23 Oktober 2018.

${ }^{25}$ Wawancara dengan KH. Gusti Tamrani, BA (tokoh masyarakat, tokoh agama) pada hari Rabu tanggal 3 Oktober 2018.
} 
Rabi'ah: Pendidikan Islam di Kabupaten Tabalong: Sekolah Islam Sebagai Gerakan Sosial

di bidang pendidikan. Sesuai dengan teori gerakan sosial, bahwa sebuah gerakan muncul apabila terbuka peluang untuk mengisi wadah yang ada, maka gerakan sosial-gerakan sosial keagamaan di Kabupaten Tabalong pun menyambut baik dengan mempresentasikan ciri khasnya keberagamaannya termasuk dalam sektor pendidikan.

Pertumbuhan sekolah Islam mulai menjamur sekitar tahun 2005-2006 ke atas. Sebagai respon atas kebutuhan masyarakat Tanjung Tabalong yang sebagian besar merupakan pekerja baik sebagai PNS maupun sebagai karyawan tambang yang memiliki jam kerja yang panjang. Sekolah Islam yang umumnya menggunakan sistem full days school di Kabupaten Tabalong cukup berkembang dan disambut baik keberadaannya sebagai alternatif lembaga pendidikan Islam selain pesantren dan madrasah. Perekonomian masyarakat yang berkembang baik menyebabkan masyarakat mampu membayar biaya pendidikan yang tidak murah untuk memenuhi kebutuhan mereka, yakni pendidikan Islam yang praktis untuk bekal keberagamaan anak-anak mereka. Padahal, masyarakat mengetahui bahwa pendidikan gratis telah diberlakukan Pemerintah Daerah Kabupaten Tabalong.

Sekolah Islam Terpadu di bawah JSIT merupakan sekolah Islam paling cepat perkembangannya. Hal ini dibuktikan dengan penambahan sekolah baru di lokasi yang berbeda namun masih wilayah kecamatan Tanjung. Sekolah Islam baru ini dikarenakan SDIT an Nahl tidak mempunyai jumlah ruangan kelas yang cukup di tempatnya yang sekarang.

Pada umumnya sekolah Islam terdapat di wilayah perkotaan, dan memang hampir semua sekolah Islam di Kabupaten Tabalong berada di wilayah suburban yakni wilayah perkotaan Tanjung. tetapi ada sekolah Islam yang berada di wilayah pedesaan yakni Sekolah Dasar Islam di bawah yayasan ponpes Al Madaniyah Jaro di Desa Nalui Kecamatan Jaro. Menariknya, sekolah Islam ini tidak berada di bawah gerakan sosial keagamaan seperti halnya sekolah Islam yang lainnya. Di samping itu kondisi wilayah pedesaan tentu 
Rabi'ah: Pendidikan Islam di Kabupaten Tabalong: Sekolah Islam Sebagai Gerakan Sosial

masyarakatnya dikenal sebagai masyarakat yang agraris, bukan masyarakat kelas menengah seperti umumnya di perkotaan.

Sekolah Islam di Kabupaten Tabalong lebih variatif dilihat dari gerakan sosial keagamaan yang menjadi backgroundnya. Gerakan tradisional modernis Muhammadiyah dengan Sekolah Dasar Islam dan SMP Alam Muhammadiyah, Gerakan sosial Hidayatullah dengan Sekolah Islam Integral, dan Sekolah Islam Terpadu dalam JSIT yakni SDIT an Nahl dan SDIT al Risalah. Masing-masing sekolah Islam memiliki konsep tentang kesalehan yang menjadi ciri khas gerakan sosial keagamaannya. Entah itu disebut santri konvergen, santri radikal, maupun santri global.

\section{F. Penutup}

Keberadaan sekolah Islam tidak terlepas dari gerakan-gerakan sosial keagamaan di Kabupaten Tabalong yang mendapatkan peluang dari pelaksanaan otonomi daerah dan pemerintah daerah yang moderat serta perekonomian daerah yang berkembang. Sekolah Islam-sekolah Islam di Kabupaten Tabalong menjadi tantangan bagi lembaga-lembaga pendidikan Islam lainnya untuk semakin berkembang dan menunjukkan ciri khas keberagamaan dalam konsep kesalehan (santrinization). 
Rabi'ah: Pendidikan Islam di Kabupaten Tabalong: Sekolah Islam Sebagai Gerakan Sosial

\section{Daftar pustaka}

Jamhari. "New Trend of Islamic Education in Indonesia." Studia Islamika 16, no. 2 (August 31, 2009). https://doi.org/10.15408/sdi.v16i2.482.

Azra, Azyumardi. "Reforms in Islamic Education: A Global Perspective Seen from the Indonesian Case." Dalam Paul Anderson, et. All (Ed), Reforms in Islamic Education,(University of Cambridge, 2011), 2014.

Bruinessen, Martin Van. Contemporary Developments in Indonesian Islam: Explaining the Conservative Turn. New ed. Institute of Southeast Asian Studies,

2013. http://gen.lib.rus.ec/book/index.php?md5=18628023122209cb46aef332 $7730148 \mathrm{c}$.

Bryner, Karen. "Piety Projects: Islamic Schools for Indonesia's Urban Middle Class," 2013.

Halim, Ilim Abdul. "Gerakan Sosial Keagamaan Nahdlatul Ulama Pada Masa Kebangkitan Nasional." Religious: Jurnal Studi Agama-Agama Dan Lintas Budaya 2, no. 1 (2017): 35-50. https://doi.org/10.15575/rjsalb.v2i1.2215.

Hawi, Akmal. "TANTANGAN LEMBAGA PENDIDIKAN ISLAM." Tadrib: Jurnal Pendidikan Agama Islam 3 (August 30, 2017): 143. https://doi.org/10.19109/Tadrib.v3i1.1388.

Hefner, Robert W. Making Modern Muslims: The Politics of Islamic Education in Southeast Asia, 2008. http://gen.lib.rus.ec/book/index.php?md5=B5FE48F2C034307C3D61A BB3E7DAAA9F.

Muhaimin. Manajemen Pendidikan (Aplikasinya dalam Penyusunan Rencana Pengembangan Sekolah / Madrasah). Prenada Media, 2015.

Machmudi, Yon. "The Emergence of New Santri in Indonesia." Journal of Indonesian Islam 2, no. 1 (2008): 69-102.

Steenbrink, Karel A. Pesantren, Madrasah, Sekolah: Pendidikan Islam Dalam Kurun Moderen. Lembaga Penelitian, Pendidikan dan Penerangan Ekonomi dan Sosial, 1986. 
Rabi'ah: Pendidikan Islam di Kabupaten Tabalong: Sekolah Islam Sebagai Gerakan Sosial

Syawaludin, Mohammad. Sosiologi Perlawanan Studi Perlawanan Repertoar Petani 1di Rengas Ogan Ilir Sumatera Selatan. Deepublish, 2017.

Tan, Charlene. Islamic Education and Indoctrination: The Case in Indonesia. Routledge, 2012.

TARROW, SIDNEY G. Power in Movement Social Movements and Contentious Politics Revised and Updated Third Edition. Cambridge Studies in Comparative Politics. Cambridge University Press, 2011. http://gen.lib.rus.ec/book/index.php?md5=077904571daf7855baf991e9 $7 \mathrm{ad} 973 \mathrm{e} 0$. 